\title{
SEISMIC BEHAVIOR OF PRECAST CONCRETE FILLED DUAL STEEL TUBE COLUMNS IN SOCKET FOUNDATIONS
}

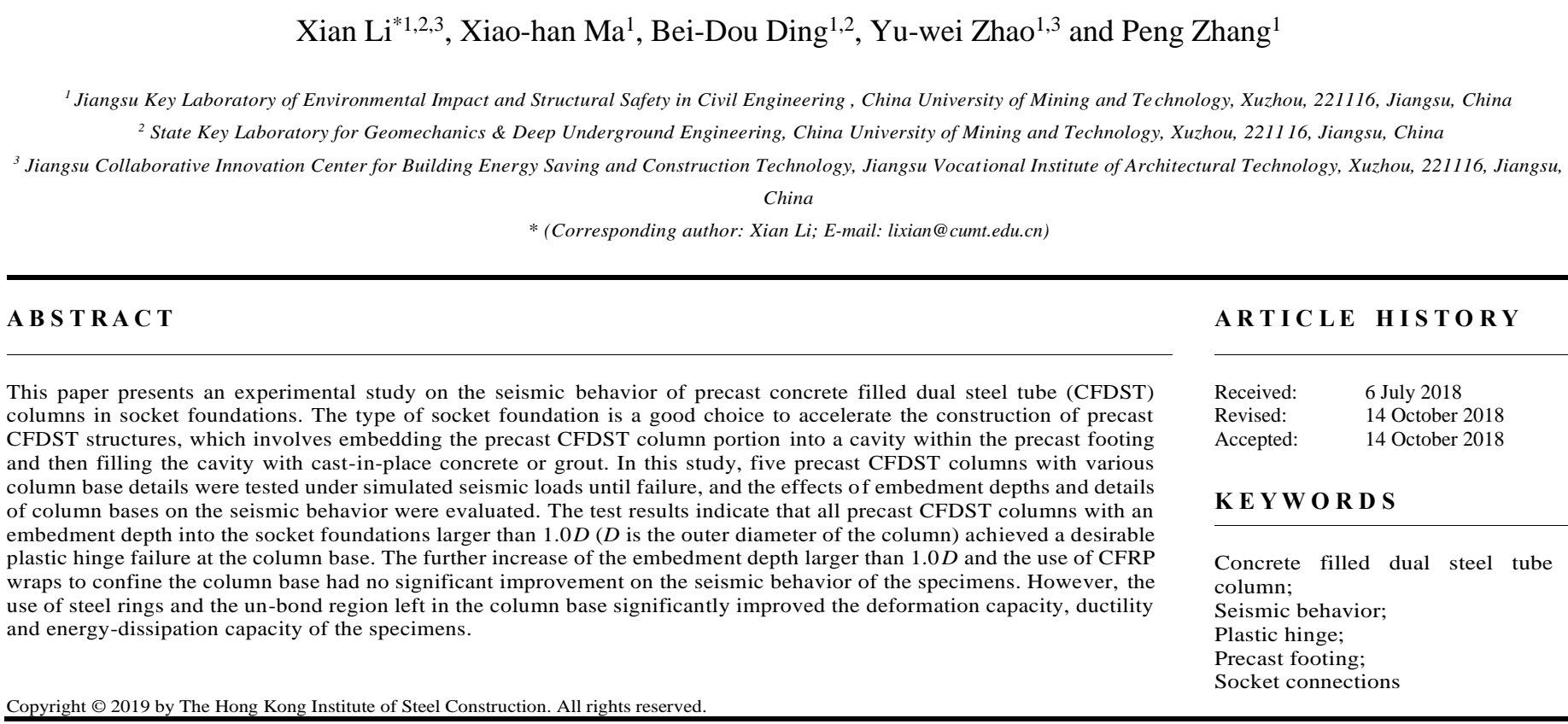

\section{Introduction}

Extensive studies have been conducted on concrete filled steel tubes (CFTs) over the past two decades, and the structural and constructional merits of CFTs are well recognized. Concrete filled dual steel tubes (CFDSTs), which consist of double concentric steel tubes with concrete sandwiched between them, can be recognized as a new type of CFT construction and have shown a great potential to be used in the construction of offshore platforms, bridge piers and high-rise buildings in recent years. Due to the existence of inner steel tubes, CFDST members exhibit some superior performance such as lighter weight, higher bending stiffness, and better earthquake- and fire-resistance behavior when compared with CFTs. To better understand the behavior of CFDSTs, previous investigations have been carried out on CFDST columns [1-9], beams [10] and beam-columns [11-12] under monotonic or cyclic loadings. However, the issues related to the behavior of CFDST column to concrete footing connections have not been fully addressed to date. The gravity and seismic loads resisted by the columns must be properly transferred down to the soil/rock through the concrete footings. Thus, the proper evaluation of the behavior of CFDST columns, particularly precast columns, in foundations is quite important for reliable CFDST construction.

In this study, the seismic behavior of precast CFDST columns in socket foundations are intended to be studied. The use of precast CFDST structures is a good choice to reduce the construction time and construction-related disruption to society. Nowadays the existing column base connections mainly includes exposed base-plate column base connections, embedded column base connections, concrete-encased column base connections and socket column base connections[13-14]. Among these column base connections, the type of socket connections is relatively most suitable for precast structures. The socket connection is usually constructed by embedding a precast CFDST column portion into a cavity within a precast concrete footing, and then the space between the cavity and the column is filled with cast-in-place concrete or grout. Lehman et al. [13] conducted experimental studies on the seismic behavior of CFT columns in socket foundations and developed design procedure for socket connections. Canha et al. [15] carried out theoretical and experimental studies on socket foundations for precast concrete structures. To date, however, the seismic behavior of precast CFDST columns in socket foundations have not been well studied yet, even the required embedment depth of CFDST columns into footings to develop a column plastic hinge failure is still not clear. In China, the required embedment depths varied from 1.0D to 2.5D (D is the diameter of the column) in the different codes and standards for CFT structures due to the lack of efficient experimental studies in this field. Therefore, this paper presents an experimental study to determine the required embedment depths of CFDST columns into concrete footings, and the effects of embedment depths and details of column bases on the seismic behavior are also to be evaluated.

\section{Experimeantal program}

\subsection{Specimen design}

Five precast CFDST columns in socket foundations were constructed and tested under simulated seismic loads, as shown in Fig. 1 and Table 1. The CFDST columns for all specimens had an identical cross section and a height of $1360 \mathrm{~mm}$ from the load point to the top surface of the precast footing. The inner and outer seamless steel tubes had a thickness of $7 \mathrm{~mm}$ and were made of Q235 steel with a nominal yield strength of 235MPa. The inner and outer steel tubes had an outer diameter of $168 \mathrm{~mm}$ and $273 \mathrm{~mm}$, respectively. Thus, the hollow ratio of the CFDST columns, which is defined as the ratio between the outside diameter of the inner steel tube and the inside diameter of the outer steel tube by Tao et al.[16], is 0.65 . Concrete was sandwiched between these two steel tubes and the inner tube was partially filled with concrete from the bottom of the tube to a height of $410 \mathrm{~mm}$ above the top surface of the concrete footing. An end annular ring with a thickness of $14 \mathrm{~mm}$ and a width of $159 \mathrm{~mm}$ was welded onto the column to transfer loads from the steel tubes and in-filled concrete to the concrete footing. The flange of the end ring projected out from the tube a distance equal to 9 times the wall thickness of the outer tube. All of the precast concrete footing had an identical dimension of $1250 \mathrm{~mm} \times 1250 \mathrm{~mm}$ in plan and $600 \mathrm{~mm}$ in depth. Each concrete footing was longitudinally and transversely reinforced at both the bottom and the top with $18 \mathrm{~mm}$-diameter HRB400 deformed bars (hot-rolled ribbed bar $\Phi 18$ with a nominal yield strength of $400 \mathrm{MPa}$ ) averagely spaced at $125 \mathrm{~mm}$. The top longitudinal bars intersecting with CFDST columns were bent downwards with a length of $200 \mathrm{~mm}$ to avoid passing through the columns. Vertical reinforcement with a diameter of $8 \mathrm{~mm}$ was used to strengthen the areas of the footings with the holes for bolts. The thickness of concrete cover was $50 \mathrm{~mm}$.

The intended test variables were the embedment depths of the CFDST columns into concrete footings and the details of column bases. The CFDST columns for specimens CFDST1 and CFDST2 had an embedment depth of $273 \mathrm{~mm}$, which is equal to the outer diameter of the column $D$, while the CFDST columns for other three specimens had an embedment depth Le of $410 \mathrm{~mm}$, which is equal to 1.5 times the outer diameter of the column $D$. The cavity for the column was located at the center of the precast footing and formed by the corrugated pipe with a diameter of $500 \mathrm{~mm}$ and a thickness of $2 \mathrm{~mm}$. To control the local buckling of the column base and enhance the ductility of the specimens, steel rings and CFRP wraps were used to confine the column base in the region 
200mm above the footing in specimens CFDST2 CFDST5. The concept of using steel and CFRP sheets to confine the CFT column base was firstly proposed by Choi et al. [17] and the efficiency of the confinement was validated by their experiments. In specimen CFDST2, two steel rings with a $299 \mathrm{~mm}-$ outer-diameter, a $10 \mathrm{~mm}$ - thickness and a $100 \mathrm{~mm}$-height were used to confine the potential plastic hinge at the column base. Therefore, a $3 \mathrm{~mm}$-wide gap was left between the steel rings

Table 1

Details of test specimens

\begin{tabular}{|c|c|c|c|}
\hline Specimen number & Footing size $\left(\mathrm{mm}^{3}\right)$ & Embedment depth $L_{\mathrm{e}}(\mathrm{mm})$ & Column base details \\
\hline CFDST1 & $1250 \times 1250 \times 600$ & $273(1.0 D)$ & Reference specimen \\
\hline CFDST2 & $1250 \times 1250 \times 600$ & $273(1.0 D)$ & The column base was confined by two steel rings with a gap. \\
\hline CFDST3 & $1250 \times 1250 \times 600$ & $410(1.5 D)$ & The column base was confined by two layers of CFRP wraps with a $2 \mathrm{~mm}$-wide gap. \\
\hline CFDST4 & $1250 \times 1250 \times 600$ & $410(1.5 D)$ & The column base was confined by two layers of CFRP wraps directly glued onto it. \\
\hline CFDST5 & $1250 \times 1250 \times 600$ & $410(1.5 D)$ & $\begin{array}{l}\text { The region from } 137 \mathrm{~mm} \text { lower than the top surface of the footing to } 200 \mathrm{~mm} \text { above the footing was } \\
\text { confined by two layers of CFRP wraps with a } 2 \mathrm{~mm} \text {-wide gap. }\end{array}$ \\
\hline
\end{tabular}

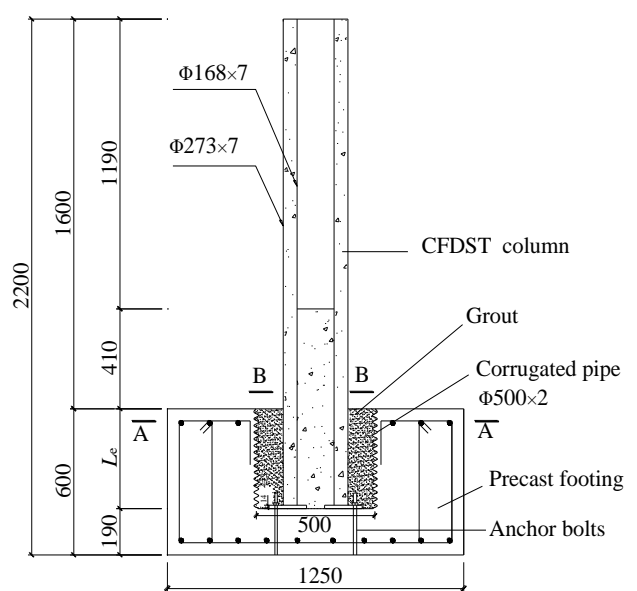

a) Dimensions of specimens
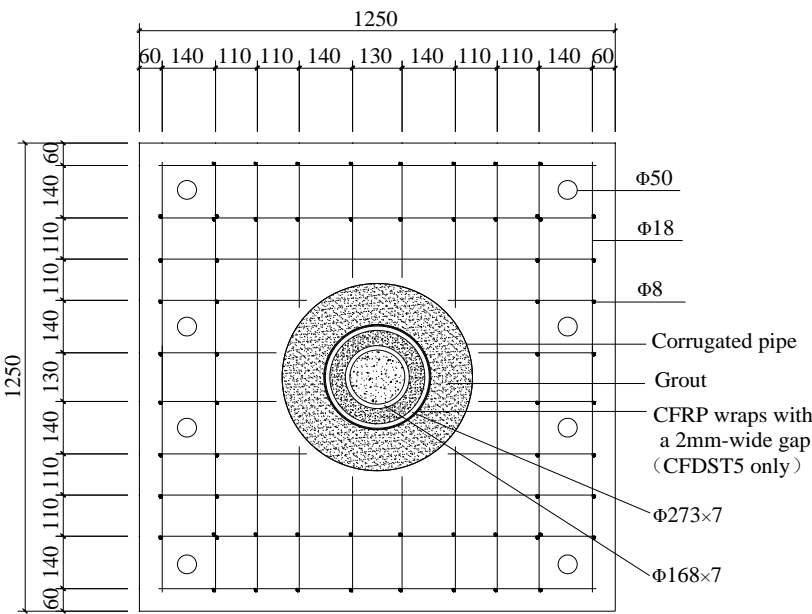

$\Phi 273 \times 7$

$\Phi 168 \times 7$

b) Section A-A

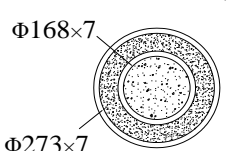

CFDST1

$\Phi 168 \times 7$

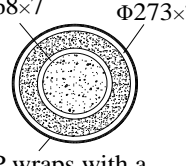

CFRP wraps with a

2mm-wide gap

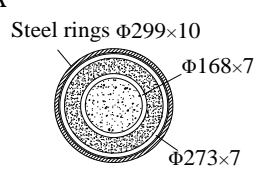

CFDST2

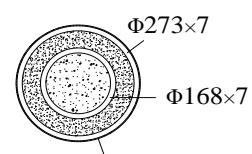

CFRP wraps glued to the tube directly
CFDST3 (CFDST5

CFDST4

c) Section B-B (the region within $200 \mathrm{~mm}$ above the footing) Fig. 1 Details of test specimens and the column steel tube. In specimens CFDST3 CFDST5, two layers of CFRP sheets with a nominal thickness of $0.167 \mathrm{~mm}$ were employed to confine the column base in the region of $200 \mathrm{~mm}$ above the top of the footing, but the confinement methods were different in these specimens. In specimen CFDST3 and CFDST5, a gap between the steel tube and the CFRP confinement was left and the gap was made by $2 \mathrm{~mm}$-thick soft foam tapes affixed on the surface of the steel tube to provide a cushioning effect. Such cushioning effect was designed to delay the participation of the CFRP wraps for possibly maximizing the deformability while minimizing the unnecessary strength enhancement. In specimen CFDST5, the CFRP confinement extended down into the footing with a height of $137 \mathrm{~mm}$. Therefore, the column had a un-bond length of $137 \mathrm{~mm}$ left in the concrete footing and the un-bond region left herein was intended to prevent the serious buckling of column by the concrete of the footing and then enlarge the plastic hinge zone of the column. In specimen CFDST4, the CFRP sheets were directly glued onto the outer steel tube.

All of the specimens were constructed according to the following steps. The CFDST columns and the reinforced concrete footings were firstly precast, and the column bases were confined by CFRP sheets or steel according to the design. Then the columns were set in the excavation, plumbed and anchored to the footings using four Grade 4.6 anchors with a diameter of $14 \mathrm{~mm}$. The voids between the columns and the corrugated pipes were lastly filled using cast-inplace grout.

\subsection{Material properties}

The measured yield strength $f_{\mathrm{y}}$ and the tensile strength $f_{\mathrm{u}}$ of both the steel tubes and the steel bars are shown in Table 2. The concrete cubic strength $f_{\mathrm{cu}}$ was obtained by compression tests of $150 \mathrm{~mm}$ concrete cubes as per the Chinese standard. The concrete cubes were cured at room temperature the same to the test specimens, and the average compressive strengths $f_{\text {cu }}$ of the concrete for footings and columns at the time of testing were 53.4MPa and 55.2MPa, respectively. The cylinder strength $f^{\prime}$ c can be calculated as 0.8 times the cubic strength $f_{\text {cu }}$. The grout used to fill the void in the corrugated pipes had a compressive strength of $80 \mathrm{MPa}$. The unidirectional CFRP sheets used to confine column bases had a width of $200 \mathrm{~mm}$ and a nominal thickness of $0.167 \mathrm{~mm}$. As provided by the manufacturer, the tensile rupture strength, average rupture strain and elastic modulus were $3062 \mathrm{MPa}, 0.0172$ and $214 \mathrm{GPa}$, respectively. The tensile strength and elastic modulus of the structural adhesive used in this test were about $42 \mathrm{MPa}$ and $3.1 \mathrm{GPa}$, respectively.

Table 2

Material properties of steel components

\begin{tabular}{llll}
\hline Components & Details & $f_{y} \quad(\mathrm{MPa})$ & $f_{u} \quad(\mathrm{MPa})$ \\
\hline Outer steel tube & $t=7 \mathrm{~mm}$ & 307 & 436 \\
Inner steel tube & $t=7 \mathrm{~mm}$ & 276 & 398 \\
Steel rings & $t=10 \mathrm{~mm}$ & 426 & 565 \\
Steel reinforcement & HPB300Ф8 & 374 & 508 \\
Steel reinforcement & HRB400Ф18 & 415 & 627 \\
\hline
\end{tabular}

\subsection{Test methods}

The experimental setup for all tests is presented in Fig. 2. The experimental setup was designed to apply lateral cyclic loadings using a horizontally positioned $500 \mathrm{kN}$ capacity hydraulic actuator to the CFDST columns in a condition of vertical cantilever. The precast concrete footings were tied to the strong floor by eight high-strength bolts and the potential slipping of the concrete footing was prevented by four hydraulic jacks. The axial load was applied to the top of 


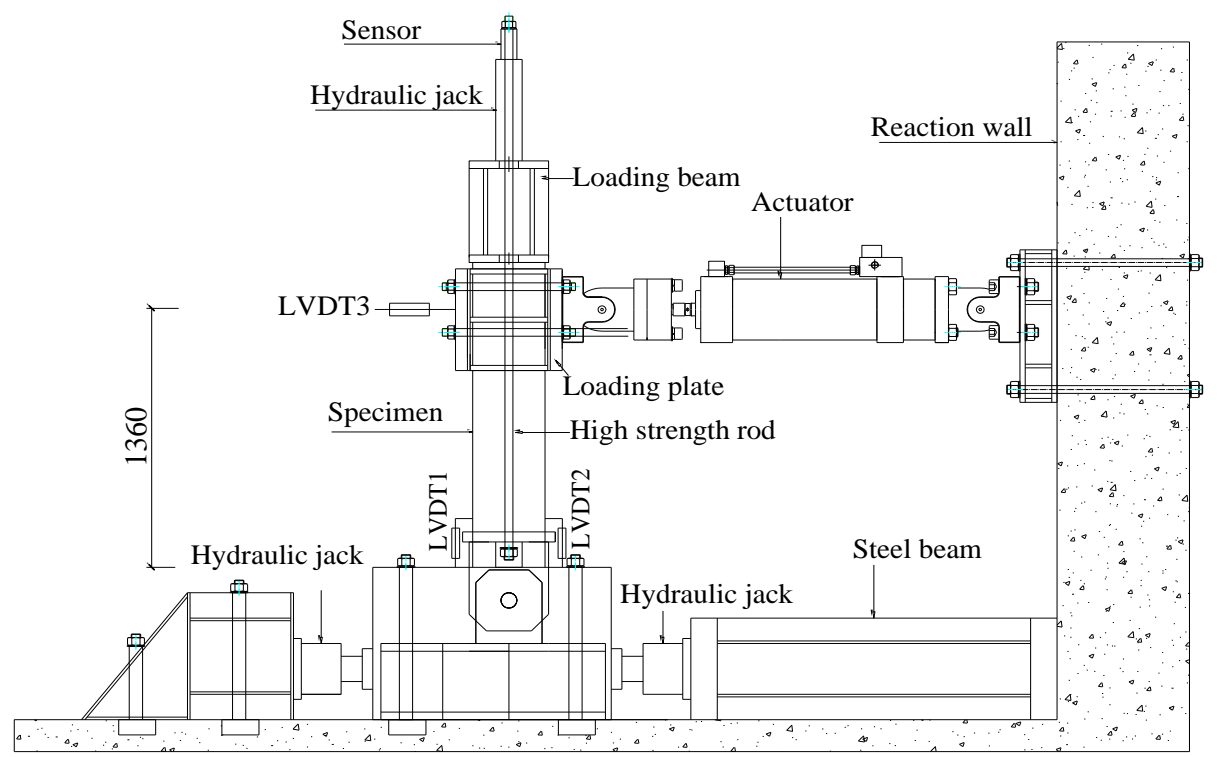

Fig. 2 Experimental setup (unit: $\mathrm{mm}$ )

the CFDST columns using a steel beam posttensioned by two vertical $50-\mathrm{mm}$ diameter high-strength steel rods. The forces of the steel rods were applied by two $1000 \mathrm{kN}$ capacity hydraulic hollow jacks and were monitored by two calibrated load cells. A specially designed pin device was connected to the bottom end of each posttensioned steel rod to eliminate the bending of the rods during the lateral loading cycles. The imposed lateral displacement at the loading point was monitored by both a separate linear potentiometer and the displacement transducer of the actuator. The curvatures of the column bases were monitored by two linear potentiometers. The corresponding lateral force was recorded by the load cell of the actuator, as shown in Fig. 2.The strain responses of the outer and inner steel tubes as well as the steel bars of the precast footing were measured by electrical resistance strain gauges.

During the testing, the axial load was maintained constantly to $650 \mathrm{kN}$, whereas the lateral loading sequences were controlled by the drift ratios of the columns at the shear force application point. The drift ratio herein was defined as the ratio of the applied displacement $(\Delta)$ to the height $(H=1360 \mathrm{~mm})$ from the loading point to the top surface of the concrete footing. One complete loading cycle for each peak lateral drift ratio was applied corresponding to an increment of peak drift ratio of $\Delta / H=0.25 \%$, until $\Delta / H=1 \%$ was reached. Subsequent loading was carried out with three complete cycles corresponding to each of the peak drift ratios of $\Delta / \mathrm{H}$ equal to $1 \%, 1.5 \%, 2 \%, 3 \%, 4 \%$ and then with two complete cycles corresponding to $\Delta / H$ equal to $5 \%, 6 \%, 7 \%$ and $8 \%$, until physical fracture of the specimens occurred.

\section{Experimental results and discussions}

\subsection{Experimental observations and failure modes}

All of the tested specimens with a column embedment depth of $1.0 \mathrm{D}$ or $1.5 D$ successfully formed a plastic hinge at the column base, indicating that the column embedment depth larger than $1.0 \mathrm{D}$ is adequate for socket connections.
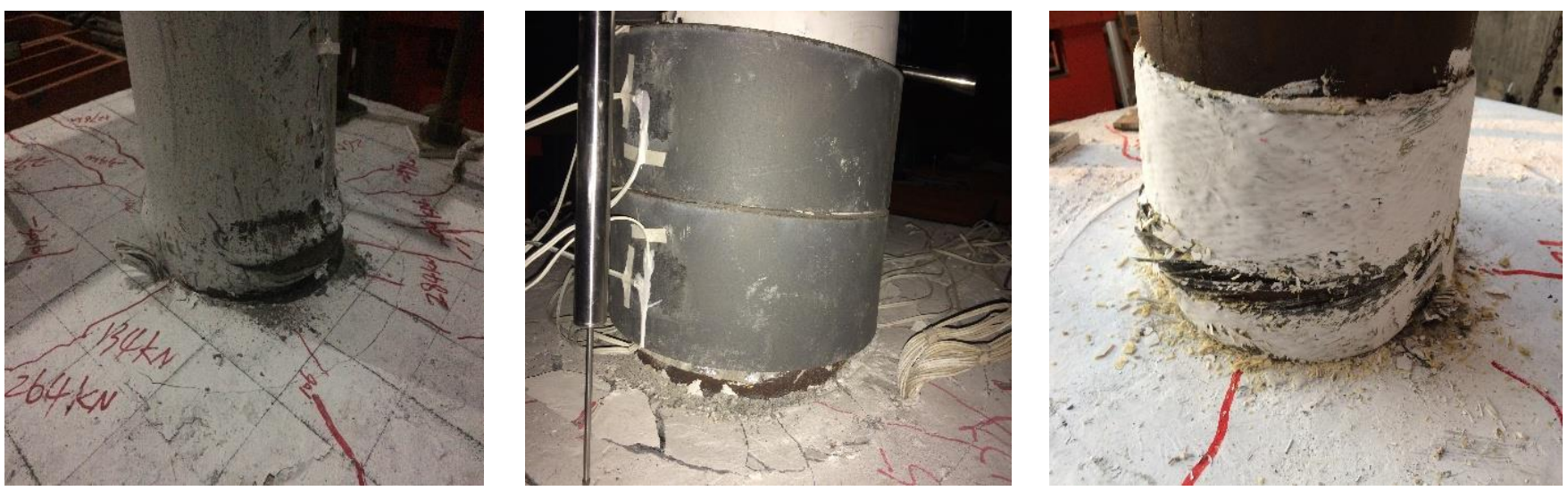

a) CFDST1
However, the specimens with a smaller embedment depth suffered more serious damage of the infilled grout at the footings. For specimen CFDST1, cracks initiated at the column-footing interface at approximately $0.75 \%$ drift ratio and these cracks remained small and local within the corrugated pipe with increasing lateral deformation until 3\% drift ratio. After that, the cracks extended out the corrugated pipe and the cracking around the corrugated pipe occurred at the third cycle of $4 \%$ drift ratio. The outer steel tube of the column started to buckle at the lateral drift ratio of $7 \%$ and was fractured at a drift ratio of $11 \%$. For specimen CFDST2 with confinement provided by two steel rings at the column base, the buckling of the steel tube was successfully prohibited and the outer steel tube was fractured at the column bottom due to too large inelastic deformation at the drift ratio of $13 \%$. The grout in the corrugated pipe suffered more serious damage due to the slight increase of the loading capacity of the specimen.

For specimens CFDST3 CFDST5 with an embedment depth of $1.5 \mathrm{D}$, the cracking of the footing became slighter. The fibers of CFRP sheets were gradually fractured due to the serious buckling of the steel tubes at the large drift ratios larger than 5\%. The use of sponge between the CFRP sheets and steel tubes slightly delayed the fracture of the CFRP fibers but had no significant effect on the deformation capacity of the specimens. Both the specimens CFDST3 and CFDST4 failed at a drift ratio of $11 \%$ due to the fracture of steel tubes. In specimen CFDST5, the un-bond region left in the footing significant delayed the fracture of both CFRP sheets and the outer steel tube. The initial yielding of the outer steel tube occurred in the un-bond region; however, with the increase of the applied displacements, the outer steel tube gradually buckled at the region above the footing and it was finally torn off during a drift ratio of $15 \%$. According to the strain measurement, the steel bars in all precast concrete footings did not yield at the failure conditions of the testing. The final failure modes of the tested specimens are presented in Fig. 3.

Fig. 3 Failure modes of tested specimens 


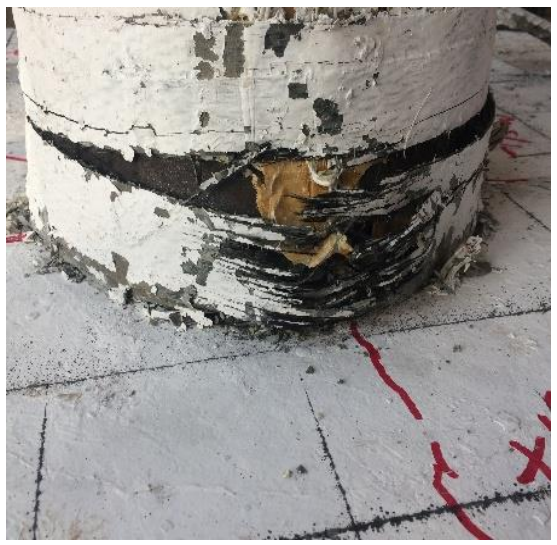

d) CFDST4

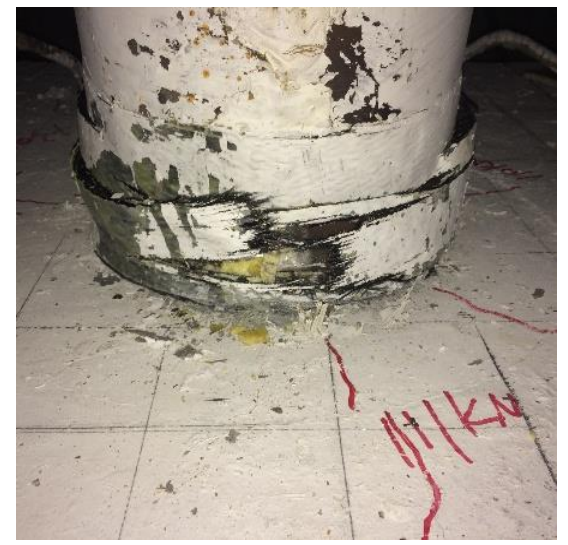

e) CFDST5

Fig. 3 Continued

\subsection{Load-deformation responses}

Fig. 4 presents the measured lateral load-deformation relationship curves of the tested specimens CFDST1 CFDST5. The yield loads Py and the peak loads Pmax of the specimens are included in Table 4. As shown in Fig. 4, all of the tested specimens exhibited stable spindle-type hysteretic loops. The strength of the specimens did not significantly deteriorate prior to the fracture of outer steel tubes. The comparison of the hysteretic loops of the specimens with embedment depths of $1.0 \mathrm{D}$ and $1.5 \mathrm{D}$ indicated that the embedment depth of $1.0 D$ is adequate to develop the full plastic flexural strength of the columns. Specimens CFDST1 and CFDST3 had the same deformation capacity equal to $11 \%$ drift ratio and the loading capacity of specimen CFDST3 was only $5.5 \%$ higher than that of specimen CFDST1. For the specimens CFDST1 and CFDST2 with an embedment depth of 1.0D, the use of steel rings to confine the potential plastic hinge in specimen CFDST2 significantly increased the deformation and loading capacities. The deformation capacity of this specimen was approximately $19.0 \%$ higher than that of specimen CFDST1, and the specimen achieved an average loading capacity of $349.75 \mathrm{kN}$ in the positive and negative loading directions, which was $13 \%$ higher than that of specimen CFDST1. The strength deterioration rate of specimen CFDST2 was also found be slow due to the good confinement of the column base. Specimens CFDST3 and CFDST4 exhibited almost the same hysteretic behavior with similar load and deformation capacities. This is because the buckling of outer steel tubes resulted in uneven stress distribution in the CFRP sheets and then the CFRP fibers were ruptured one by one due to the limited ultimate deformability. For specimen CFDST5, the loading capacity and ultimate displacement were $338 \mathrm{kN}$ and $204 \mathrm{~mm}$, respectively, which were $3.4 \%$ and $36.36 \%$ higher than the corresponding values of specimen CFDST3. That is to say, the un-bond region left in the column-footing interface had no significant effect on the loading capacity but significantly improved the deformation capacity of the specimen. The improvement of the deformation capacity was attributed to that the plastic deformation initially occurred in the un-bond region; however, with the increase of the applied loads, the further plastic deformation in the un-bond region were prohibited by the concrete footing and then the plastic deformation was enlarged to the region above the top surface of the footing. Thus, the un-bond region left in the column-footing interface is a good detail for the column base connection to enlarge the plastic zone of CFDST columns.

\subsection{Moment-curvature responses}

The average curvature $\Phi$ of the plastic hinge was measured using LVDTs and then calculated as follows.

$\phi=\frac{\Delta_{1}-\Delta_{2}}{b_{t} l_{t}}$

where $\Delta_{1}$ and $\Delta_{2}$ are the vertical displacements of LVDT1 and LVDT2 shown in Fig. $2 ; b_{\mathrm{t}}$ is the distance between the two LVDTs; and $l_{t}$ is the measured length of the LVDTs, equal to $200 \mathrm{~mm}$ herein.

The relationship curves between the moments at the column-footing interfaces and the average curvatures of the plastic hinges are presented in Fig. 5. It can be found that, with the increase of the column embedment depth, the plastic deformation at the column bases developed more fully and thus the moment-curvature curves became flatter. The use of steel rings in specimen
CFDST2 was effective to confine the potential plastic hinge and resulted in much larger and more stable hysteric loops. Specimen CFDST4 with a confinement of the column base using CFRP sheets glued on the steel tube directly exhibited slight improvement of the plastic deformation at the plastic hinge when compared with specimen CFDST3. For specimen CFDST5, though the specimen exhibited the most favorable deformation capacity, its momentcurvature curve at the column base was much thinner. The results further verified the fact that serious plastic deformation of the column developed at the un-bond region in the concrete footing.

\subsection{Stiffness and stiffness degradation}

In this study, both the peak-to-peak stiffness and normalized stiffness, as shown in Fig. 6, were adopted to evaluate the stiffness characteristics of the tested specimens. The peak-to-peak stiffness is defined as the ratio of the peak shear load at the first cycle of each deformation level to their corresponding displacement, while the normalized stiffness is obtained by the peak-to-peak stiffness divided by the initial stiffness. The normalized stiffness can reflect the stiffness degradation rate of each specimen and it is plotted in Fig. 6b. As shown in Fig. 6, the initial stiffness of all of the tested specimens varied between $9.64 \mathrm{kN} / \mathrm{mm}$ and $11.13 \mathrm{kN} / \mathrm{mm}$, and with increasing applied drift ratios, the stiffness degraded gradually. Specimens CFDST1 and CFDST3 had almost identical peak-to-peak at different drift ratios and stiffness degradation rates, indicating again that the embedment depth of $1.0 \mathrm{D}$ is adequate for the socket connections for CFDST columns. The use of steel rings had no significant effect on the initial stiffness but resulted in relatively slow stiffness degradation. The use of CFRP sheets directly glued onto the steel tube slightly increased the initial stiffness of specimen CFDST4 but had no significant effect on the stiffness degradation rate due to gradual fracture of fibers at large drift ratios. Specimen CFDST5 with a un-bond region left in the concrete footing had a reduced initial stiffness since the gap between the column and the footing in the un-bond region increased the column height. However, the stiffness degradation became slow after the applied drift ratio of 5\% due to the confinement at the column base provided by the concrete footing and CFRP sheets.

Table 4 shows the predicted and measured initial elastic stiffness of each specimen. The theoretically predicted elastic stiffness $K_{\mathrm{e}}$ of the tested specimens can be determined using the Eq. 2 for cantilever beams.

$K_{e}=\frac{\pi E I}{L^{3}}$

where $E I$ is the elastic section flexural stiffness of a CFDST column; $L$ is the length of an fixed column; for specimen CFDST5, the fixed end was assumed to be located at the section $0.5 \mathrm{D}$ lower than the top surface of the footing due to the existence of the gap. As for the elastic section flexural stiffness $E I$ of the CFDST column, different codes give different calculation methods. In general, the total initial flexural stiffness $(E I)$ of a CFDST column is a sum of the flexural stiffness $\left(E_{\mathrm{s}} I_{\mathrm{si}}\right)$ of the inner tube and the flexural stiffness $\left(E I_{\mathrm{osc}}\right)$ contributed by the outer tube together with the infilled concrete.

$E I=E_{s} I_{s i}+E I_{\mathrm{osc}}$ 


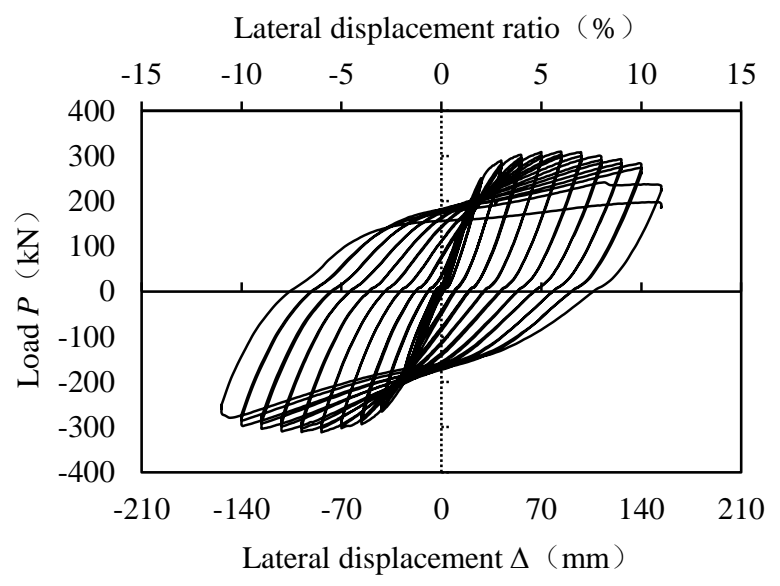

a) CFDST1

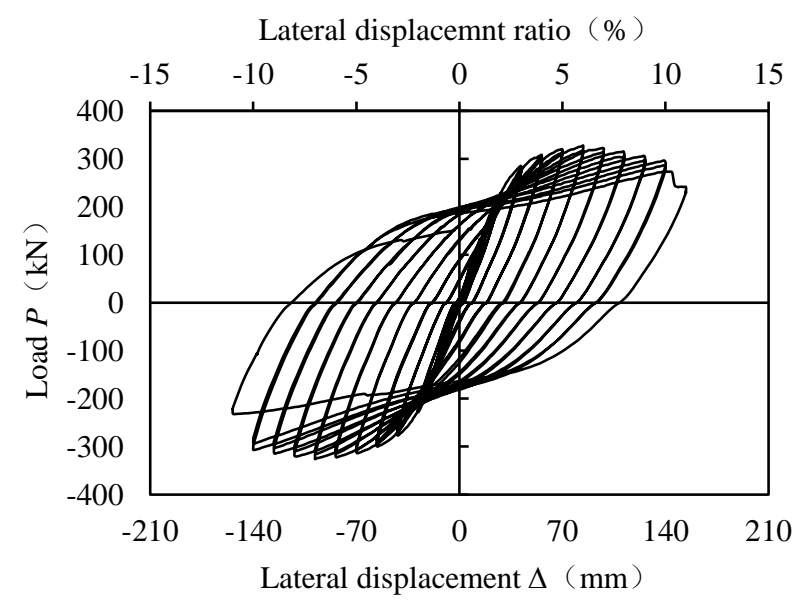

c) CFDST3

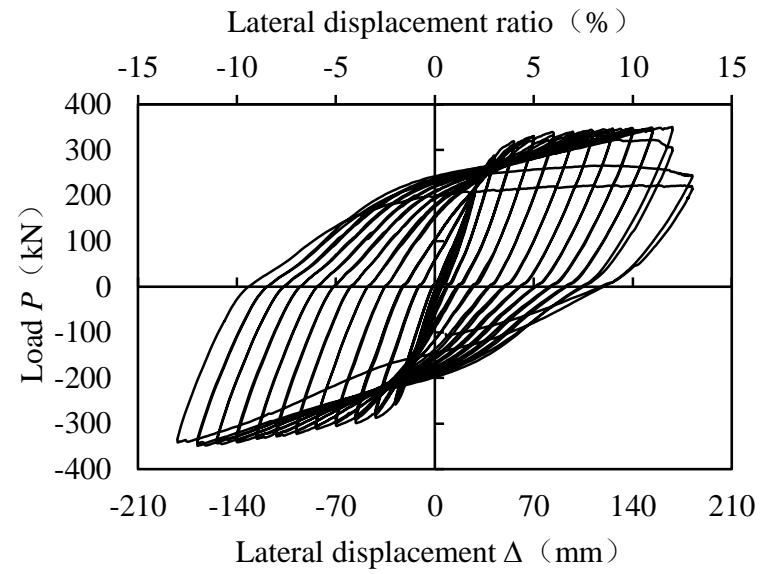

b) CFDST2

Lateral displacement ratio $(\%)$

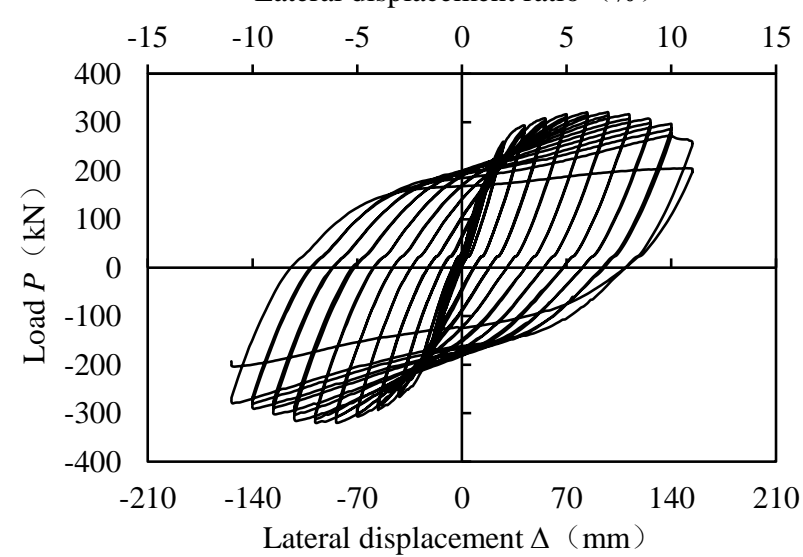

d) CFDST4

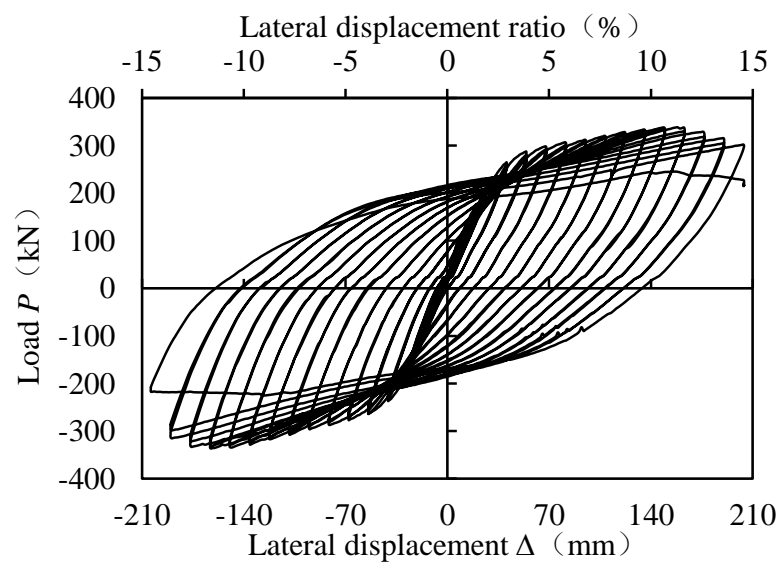

e) CFDST5

Fig. 4 Hysteretic curves of tested specimens

$E I_{\mathrm{osc}}=E_{\mathrm{s}} I_{\mathrm{so}}+E_{\mathrm{c}} I_{\mathrm{c}}$

where $E_{\mathrm{s}}=206000 \mathrm{MPa}$ and $E_{\mathrm{c}}=450 f_{\mathrm{cu}} \mathrm{MPa}$ are the elastic modulus of the steel tubes and infilled concrete, respectively. $I_{\mathrm{so}}$ and $I_{\mathrm{c}}$ are the moment of inertia for outer steel tube and the gross section of infilled concrete, respectively.

\section{-AIJ [19]}

$E I_{\mathrm{osc}}=E_{\mathrm{s}} I_{\mathrm{so}}+0.2 E_{\mathrm{c}} I_{\mathrm{c}}$

where $E_{\mathrm{s}}=205800 \mathrm{MPa} ; E_{c}=21000 \sqrt{f_{c}^{\prime} / 19.6} \mathrm{MPa}$, and $f_{\mathrm{c}}^{\prime}$ is the cylinder compressive strength of concrete.

-AISC-LRFD[20]
$E I_{\mathrm{osc}}=E_{\mathrm{s}} I_{\mathrm{so}}+C_{1} E_{\mathrm{c}} I_{\mathrm{c}}$

where $E_{\mathrm{s}}=200000 \mathrm{MPa} ; E_{c}=0.043 w_{c}^{1.5} \sqrt{f_{c}^{\prime}} \mathrm{MPa} ; w_{\mathrm{c}}$ is the weight of infilled concrete per unit volume; $A_{\mathrm{s}}$ and $A_{\mathrm{g}}$ are the cross-sectional areas of steel section and gross section, respectively.

- Eurocode 4[21]

$E I_{\mathrm{osc}}=E_{\mathrm{s}} I_{\mathrm{so}}+0.6 E_{\mathrm{c}} I_{\mathrm{c}}$

where $E_{\mathrm{s}}=206000 \mathrm{MPa} ; E_{c}=9500\left(f_{c}^{\prime}+8\right)^{1 / 3} \mathrm{MPa}$. 


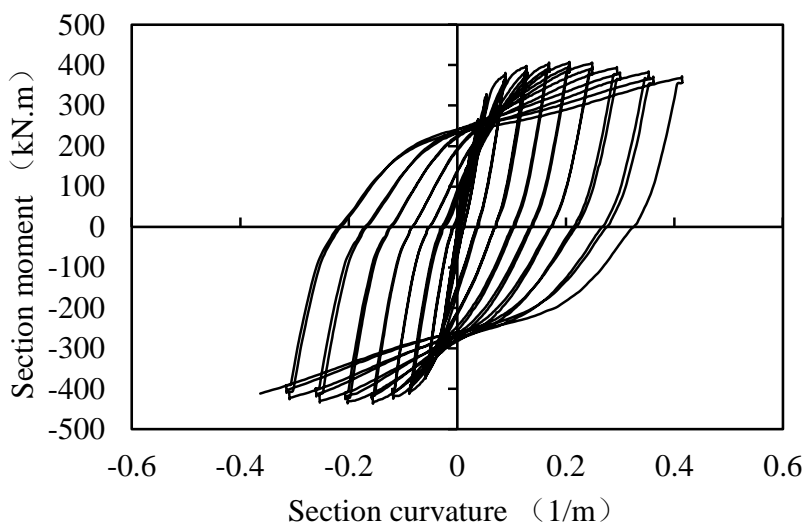

a) CFDST1

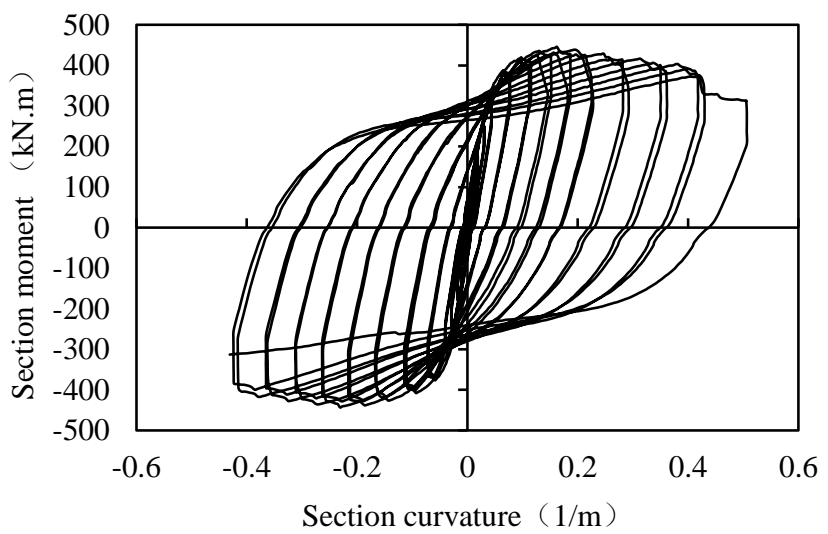

c) CFDST3

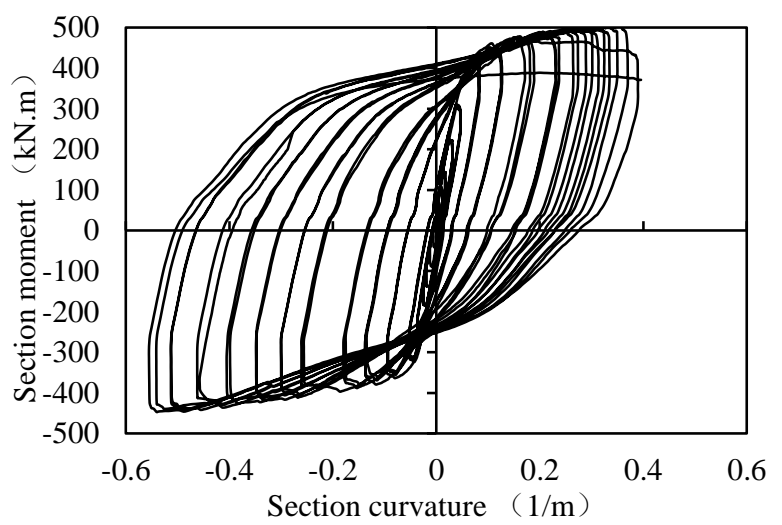

b) CFDST2

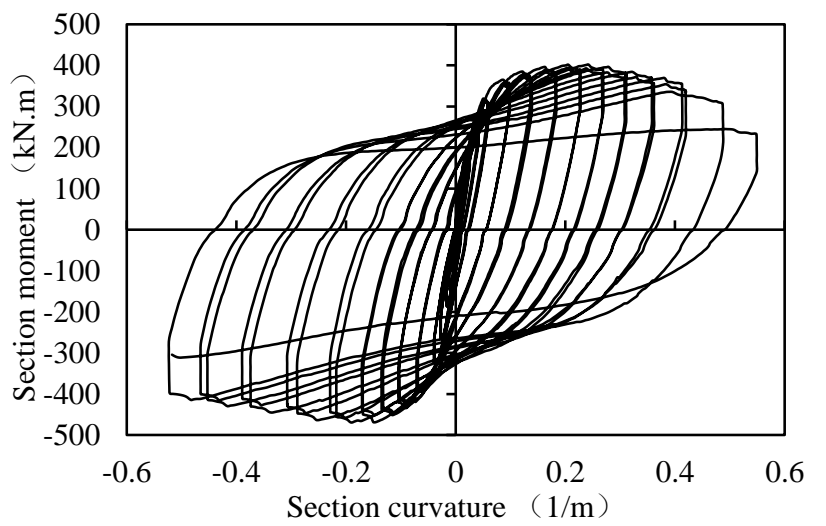

d) CFDST4

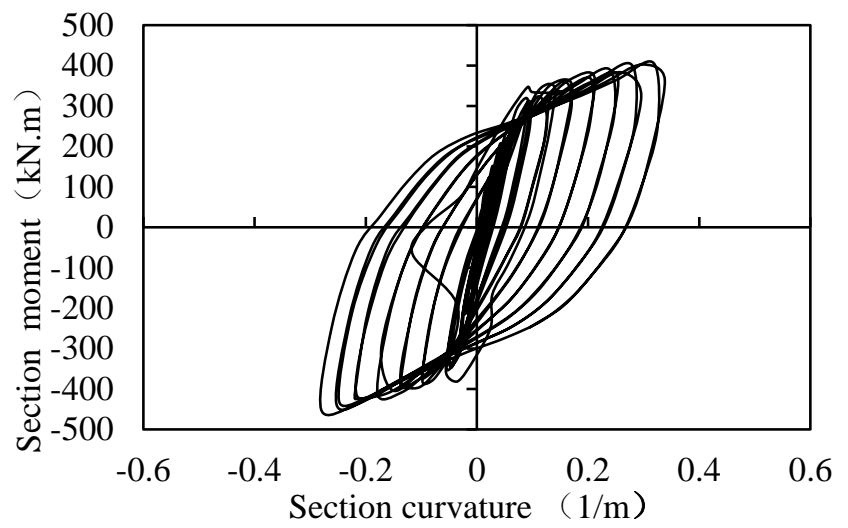

e) CFDST5

Fig. 5 Moment-curvature relationship curves of tested specimens

\section{$C_{1}=0.25+0.3 A_{\mathrm{s}} / A_{\mathrm{g}} \leq 0.7$}

where $E_{\mathrm{s}}=200000 \mathrm{MPa} ; E_{c}=0.043 w_{c}^{1.5} \sqrt{f_{c}^{\prime}} \mathrm{MPa} ; w_{\mathrm{c}}$ is the weight of infilled concrete per unit volume; $A_{\mathrm{s}}$ and $A_{\mathrm{g}}$ are the cross-sectional areas of steel section and gross section, respectively.

- Eurocode 4[21]

$E I_{\mathrm{osc}}=E_{\mathrm{s}} I_{\mathrm{so}}+0.6 E_{\mathrm{c}} I_{\mathrm{c}}$

where $E_{\mathrm{s}}=206000 \mathrm{MPa} ; E_{c}=9500\left(f_{c}^{\prime}+8\right)^{1 / 3} \mathrm{MPa}$.

The comparisons of the measured initial stiffness $K_{\mathrm{t}}$ and the predicted values are presented in Table 3 , where $K_{\mathrm{e}-\mathrm{Bs}}, K_{\mathrm{e}-\mathrm{AIJ}}, K_{\mathrm{e}-\mathrm{AISC}}$ and $K_{\mathrm{e}-\mathrm{EC} 4}$ were the predicted results based on the code provisions BS5400, AIJ, AISC-LRFD and Eurocode 4, respectively. It can be found that though all of the tested specimens in socket foundations achieved a column plastic hinge failure, the measured initial stiffness of all specimens was lower than the predicted values. BS5400, AISC-LRFD and Eurocode 4 gave similar predicted results about 2 times the measured values, while the predicted stiffness by AIJ code was relatively close to the measured values with the ratios $K_{\mathrm{t}} / K_{\text {e-AIJ }}$ varying between 0.58 and 0.76 . The overestimation of the flexural stiffness of CFDST columns in socket foundations is mainly due to the over-estimation of the rigidity of socket connections. The study conducted by Hsu et al. [22] indicated that it was too costly to achieve a rigid socket connection in construction projects, and a coefficient $\alpha$ should be employed to account for the effectiveness of the base connections. Since the coefficient $\alpha$ proposed by Hsu et al. [22] was obtained by testing of solid square CFT columns embedded into concrete footings, in this study the coefficient $\alpha$ was further modified using a factor $I / I_{\mathrm{sq}}$ to account for the differences between the solid square and the CFDST columns. Thus, the elastic stiffness $K_{\text {e-Hsu }}$ can be calculated as follows for design purposes.

$K_{e-H \mathrm{su}}=\frac{\alpha E I}{L^{3}}$ 
$\alpha=\left[-0.4763\left(\frac{L_{e}}{D}\right)^{2}+1.627\left(\frac{L_{e}}{D}\right)+1.4313\right] \frac{I}{I_{s q}} \leq 3$

where $I_{\mathrm{sq}}$ is the moment of inertia for a solid square CFT column that has a square steel tube with the thickness and the width the same to the outer steel tube of CFDST section.
Table 3 also presents the predicted stiffness based on Eqs. (8) and (9). In these equations, the elastic section flexural stiffness $E I$ of the CFDST column was taken according to AIJ code. It can be found from Table 3 that, except specimen CFDST5 with more complicated connection details, the tested specimens got reasonable predicted stiffness based on Eqs. (8) and (9) with the ratios $K_{\mathrm{t}} / K_{\mathrm{e}-\mathrm{Hsu}}$ varying between 0.95 and 1.04 .
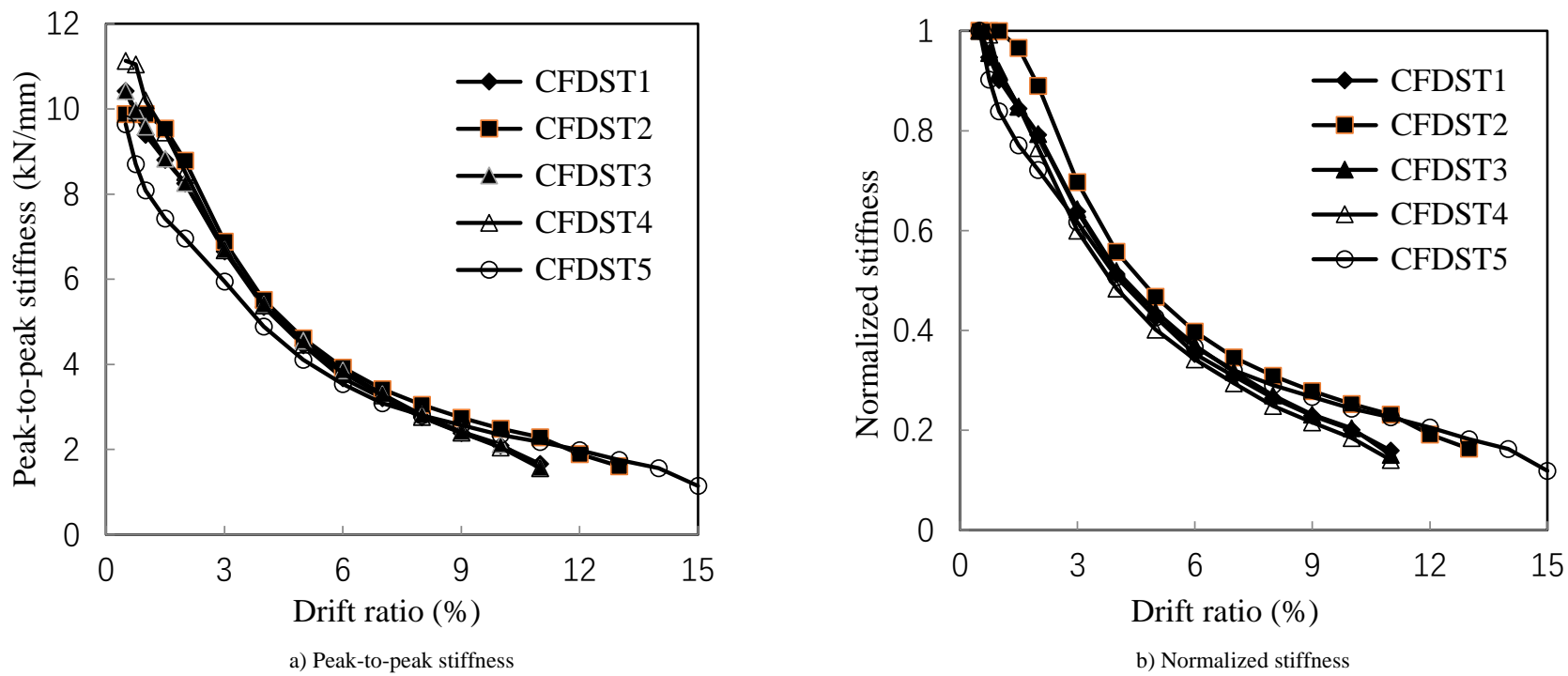

Fig. 6 Stiffness characteristics

Table 3

Comparisons between predicted initial stiffness and test results

\begin{tabular}{|c|c|c|c|c|c|c|c|c|c|c|c|}
\hline Specimens & $K_{\mathrm{t}}$ & $K_{\mathrm{e}-\mathrm{Bs}}$ & $\frac{K_{t}}{K_{e-B s}}$ & $K_{\text {e-AIJ }}$ & $\frac{K_{t}}{K_{e-A I J}}$ & $K_{\text {e-AISC }}$ & $\frac{K_{t}}{K_{e-A I S C}}$ & $K_{\mathrm{e}-\mathrm{EC} 4}$ & $\frac{K_{t}}{K_{e-E C 4}}$ & $K_{\mathrm{e}-\mathrm{Hsu}}$ & $\frac{K_{t}}{K_{e-H s u}}$ \\
\hline CFDST1 & 10.45 & 20.93 & 0.50 & 16.90 & 0.62 & 20.51 & 0.51 & 20.16 & 0.52 & 10.00 & 1.04 \\
\hline CFDST2 & 9.88 & 20.93 & 0.47 & 16.90 & 0.58 & 20.51 & 0.48 & 20.16 & 0.49 & 10.00 & 0.99 \\
\hline CFDST3 & 10.42 & 20.93 & 0.50 & 16.90 & 0.62 & 20.51 & 0.51 & 20.16 & 0.52 & 10.92 & 0.95 \\
\hline CFDST4 & 11.13 & 20.93 & 0.53 & 16.90 & 0.66 & 20.51 & 0.54 & 20.16 & 0.55 & 10.92 & 1.02 \\
\hline CFDST5 & 9.64 & 15.69 & 0.61 & 12.67 & 0.76 & 15.38 & 0.63 & 15.12 & 0.64 & 8.19 & 1.18 \\
\hline
\end{tabular}

\subsection{Ductility}

The ductility of the tested specimens is presented in Table 4. The displacement ductility factor $\mu$ is defined as the ratio of the displacement at ultimate stage $\Delta_{u}$ and that at the yield stage $\Delta_{y}$, where the former is obtained at $85 \%$ of the maximum capacity after reaching a peak load. The yield displacement is determined by the tangent method and the definition of the yield point can be found in Reference [11]. According to ASCE/SEI 41[23], the ductility capacity of the tested specimens can be classified as low if $\mu$ is less than 2; moderate if it is between 2 and 5, and high if $\mu$ is greater than 5 .

As shown in Table 4, the tested specimens exhibited good ductility with the ductility factors varying between 3.97 and 5.09. The increase of the column embedment depth to be larger than $1.0 \mathrm{D}$ had no significant effect on the ductility of the specimens. The confinement of the potential plastic hinges using steel rings and CFRP sheets delayed the local plastic buckling of the tested specimens and thus improved the ductility of the specimens. The ductility factor of specimen CFDST2 was $33.4 \%$ larger than that of specimen CFDST1. The unbond region left in the footing of specimen CFDST5 also resulted in an improved ductility factor equal to 5.09 , which was $28.2 \%$ greater than that of specimen CFDST3.

\subsection{Energy dissipation capacity}

The energy dissipation capacity of the tested specimens under cyclic loadings was evaluated by two indices: energy dissipation index $E_{\mathrm{h}}$ and cumulative dissipated energy. The energy dissipation index Eh is defined as the ratio of total energy dissipation (area $S_{\mathrm{ABCDE}}$ ) at the first cycle of each drift level to the corresponding elastic potential energy (areas $S_{\mathrm{OBF}}+S_{\mathrm{ODG}}$ ), as shown in Fig. $7 \mathrm{a}$. The total energy dissipation is the area enclosed by the load-deformation hysteresis loops of specimens. The specimens with a larger energy dissipation index $E_{\mathrm{h}}$ usually show a greater ability to dissipate energy.

As seen from Fig. 7, when the lateral drift ratios were less than $2 \%$, the tested specimens were almost elastic and the dissipated energy of the specimens was very small. When the applied drift ratios larger than $2 \%$, both the energy dissipation index $E_{\mathrm{h}}$ and cumulative dissipated energy of each specimen increased obviously with the increase of the applied drift ratios, and the energy dissipation index did not show obvious degradation with the increase of the number of cycles at each lateral drift ratio. The comparison of specimens CFDST1 and CFDST2 showed that at the drift ratio less than $2.0 \%$, these two specimens had the same energy dissipation index and cumulative dissipated energy due to the gap left between the steel rings and the column base in specimen CFDST2. However, at the large drift ratios, since the steel rings effectively delayed the local buckling of the column base, specimen CFDST2 achieved a cumulative energy dissipation capacity much better than specimen CFDST1. At the failure condition, the cumulative dissipated energy of CFDST2 was $1198 \mathrm{~kJ}$, which was 1.68 times that of specimen CFDST1. However, the energy dissipation index of specimen CFDST2 was inferior to that of specimen CFDST1 due to the increase of the loading capacity and the elastic potential energy. The increase of the embedment depth and the use of CFRP sheets showed slight improvement in the energy dissipation capacities of the tested specimens, as evidenced by the test results of specimens CFDST1, CFDST3 and CFDST4. Specimen CFDST5 exhibited lower energy dissipation index and energy dissipation capacity when compared with other specimens at the small drift ratios; however, this specimen had the best deformation capacity and thus had the largest cumulative energy dissipation equal to $1478 \mathrm{~kJ}$ prior to failure. Thus, the detail using the un-bond region between the concrete footing and the column base is the simplest and the most effective method to enhance the energy dissipation capacity of the CFDST columns in socket foundations. 
Table 4

Test results of specimens

\begin{tabular}{|c|c|c|c|c|c|c|c|}
\hline Specimens & Loading direction & $P_{\mathrm{y}}(\mathrm{kN})$ & $P_{\max }(\mathrm{kN})$ & $\Delta_{\mathrm{y}}(\mathrm{mm})$ & $\Delta_{\mathrm{u}}(\mathrm{mm})$ & $\mu$ & Average $\mu$ \\
\hline \multirow{2}{*}{ CFDST1 } & positive & 262.48 & 310.03 & 31.1 & 136.12 & 4.38 & \multirow{2}{*}{3.98} \\
\hline & negative & -262.13 & -311.54 & -41.8 & -149.56 & 3.58 & \\
\hline \multirow{2}{*}{ CFDST2 } & positive & 277.87 & 350.51 & 36.2 & 163.21 & 4.51 & \multirow{2}{*}{5.31} \\
\hline & negative & -261.24 & -348.99 & -28.9 & -176.78 & 6.12 & \\
\hline \multirow{2}{*}{ CFDST3 } & positive & 262.11 & 327.71 & 34.2 & 136.12 & 3.98 & \multirow{2}{*}{3.97} \\
\hline & negative & -249.84 & -326.08 & -34.3 & -136.12 & 3.97 & \\
\hline \multirow{2}{*}{ CFDST4 } & positive & 258.38 & 320.71 & 26.1 & 136.23 & 5.22 & \multirow{2}{*}{4.40} \\
\hline & negative & -259.26 & -320.36 & -37.9 & -135.98 & 3.59 & \\
\hline \multirow{3}{*}{ CFDST5 } & positive & 221.14 & 338.56 & 30.0 & 190.41 & 6.35 & \multirow{3}{*}{5.09} \\
\hline & & & & & & & \\
\hline & negative & -255.34 & -336.79 & -49.9 & -190.41 & 3.82 & \\
\hline
\end{tabular}

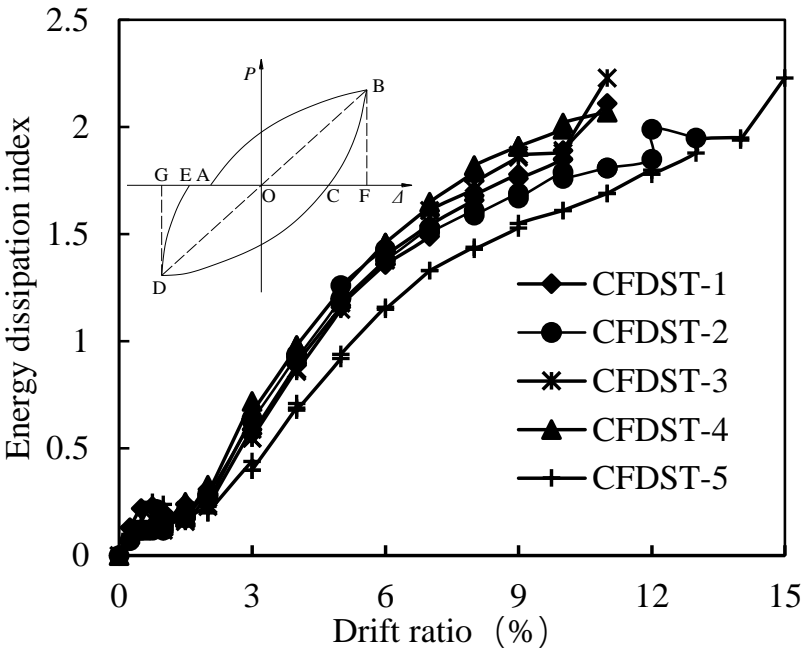

a) Energy dissipation index

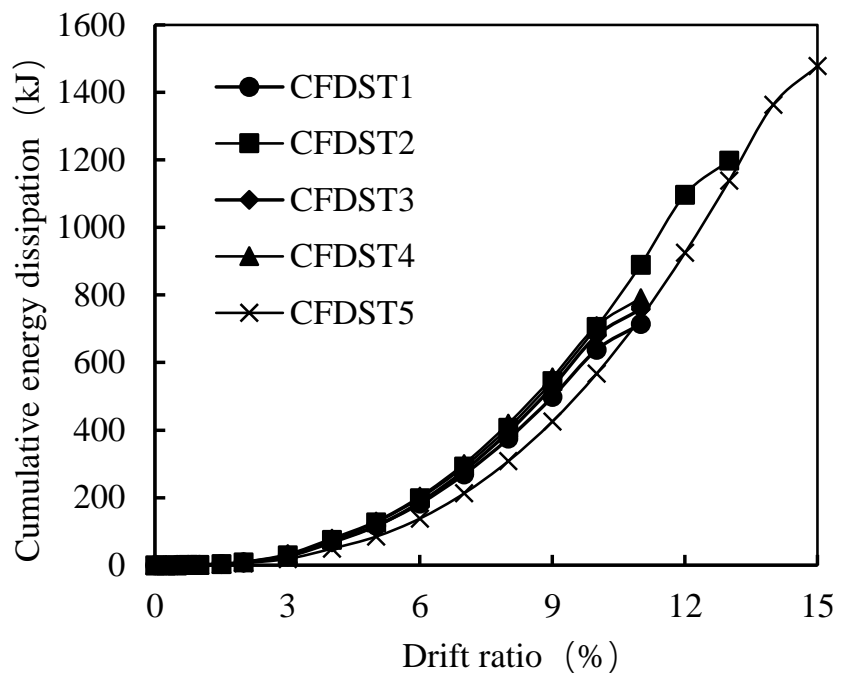

b) Cumulative energy dissipation

Fig. 7 Energy dissipation of tested specimens

\subsection{Strain responses}

The monitoring of the strains of the steel tubes can reveal the stress distribution of the tested specimens under cyclic loads. The labels of the strain gauges on outer and inner steel tubes at the embedded regions and the plastic hinge zones are presented in Fig. 8 and the typical strain distributions of outer and inner steel tubes at the embedded regions are presented in Figs. 9 and 10. The steel bars in the concrete footings got the strain values lower than $1000 \mu \varepsilon$ even at the failure conditions of the tested specimens and thus the strain distribution of the steel bars were not shown herein. According to the material tests, the outer and inner steel tubes yielded when the strain values larger than $1490 \mu \varepsilon$ and $1340 \mu \varepsilon$, respectively. It can be found that both the strain values of the outer and inner steel tubes reduced with the increase of the distances to the top surfaces of the footings. The outer and inner steel tubes yielded at the regions within about $1.0 \mathrm{D}$ embedment depth when the applied drift ratios were larger than $2.0 \%$, as evidenced by Fig. 9a. The comparison between the strain distribution of specimens CFDST1 and CFDST3 shown in Figs. 9b and 9c can be found that the strains of the inner steel tubes in the embedded region increased much more rapidly when the embedment depth of the column base increased. This result indicated that the increase of the embedment depth could more effectively motivate the contribution of inner steel tubes. As for the strain at the plastic hinge zones, the outer steel tubes for all specimens yielded at the measured zones $350 \mathrm{~mm}$ above the footing surfaces. However, for the inner steel tubes, the strain distribution of the tested specimens showed significant difference due to the different connection details. As shown in Fig. 10, the use of steel rings and CFRP wraps resulted in larger strain values at the column- footing surfaces, and the un-bond region left in specimen CFDST5 resulted in smaller strain value of the inner steel tube at the plastic hinge above the footing. It can be also found that at the drift ratios lower than $1 \%$, the strain of inner steel tube was nearly zero, indicating that the contribution of inner steel tubes to the strength and initial stiffness cannot effectively motivated.

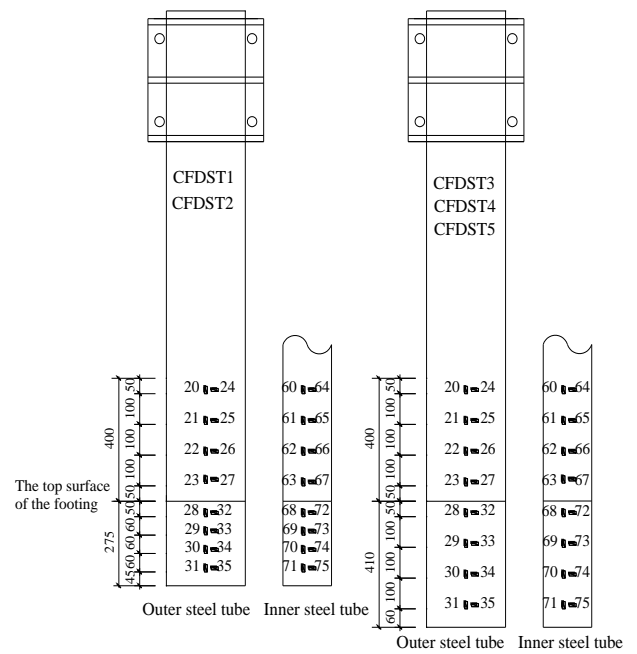

Fig. 8 Labels of strain gauges on outer and inner steel tubes 


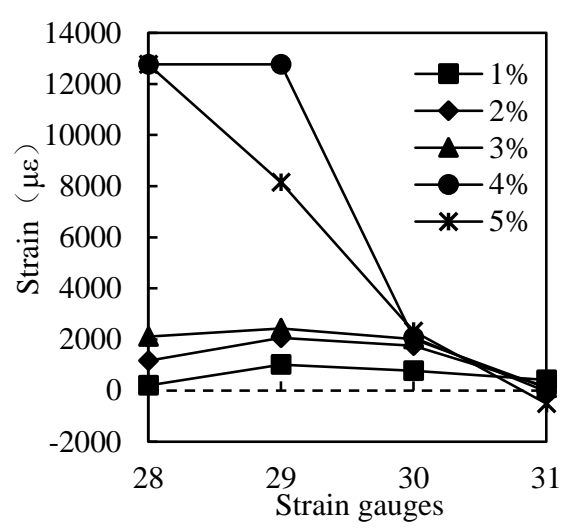

a) Outer steel tube of specimen CFDST4

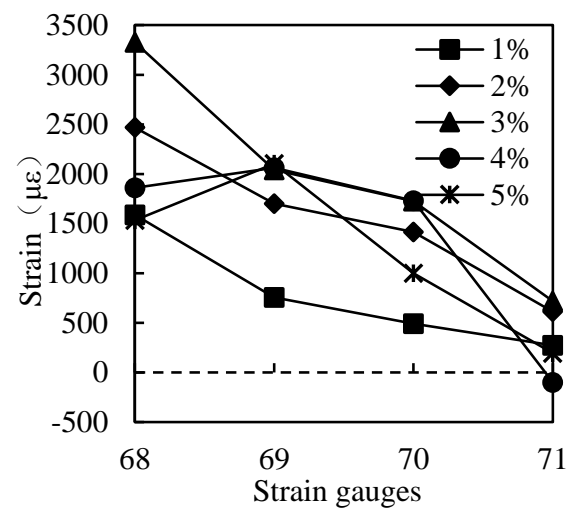

b) Inner steel tube of specimen CFDST1

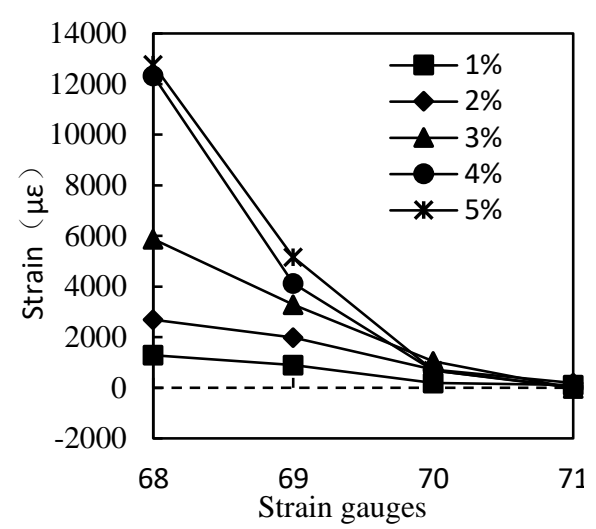

c) Inner steel tube of specimen CFDST3

Fig. 9 Typical strain distributions of steel tubes at embedded regions

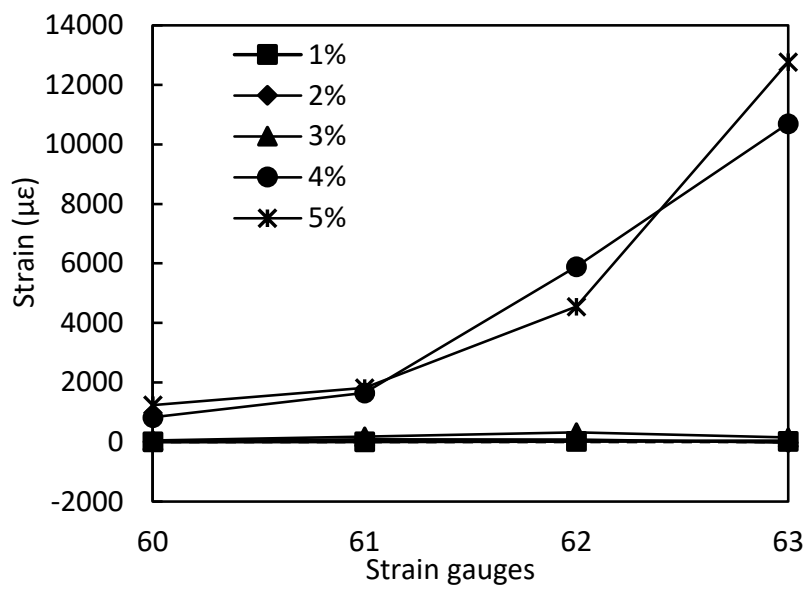

a) Specimen CFDST2

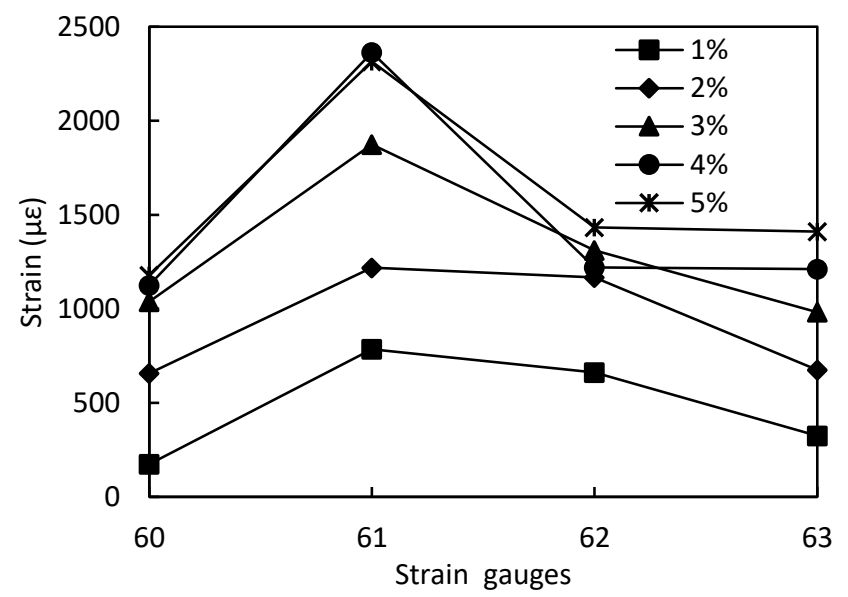

b) Specimen CFDST5

Fig. 10 Typical strain distributions of inner steel tubes at potential plastic hinge zones

\section{Summary and conclusions}

An experimental investigation on the seismic behavior of five precast concrete filled dual steel tube columns in socket foundations was conducted. The effects of the embedment depths and the details of column bases on the seismic behavior were evaluated. The following conclusions can be drawn from this study.

- The type of socket foundation is a viable choice for precast CFDST columns. The embedment depth of $1.0 \mathrm{D}$ is adequate to achieve the column plastic hinge failure and both the outer and the inner steel tubes of the tested specimens yielded in the embedded regions and the plastic hinge zones at the final conditions. The further increase of the embedment depth larger than $1.0 \mathrm{D}$ had no significant effect on the seismic behavior of the precast CFDST columns in socket foundations.

- The use of steel rings can effectively prevent the local elastic-plastic buckling of outer steel tubes, and thus can effectively improve the deformation capacity, ductility and energy-dissipation capacity of the specimens.

- The use of CFRP wraps had no significant effects on the load-deformation responses of the tested specimens due to the gradual fracture of the fibers but resulted in fatter and more stable moment-curvature relationship curves at the plastic hinges.

- The un-bond region left in the concrete footing can enlarge the plastic hinge zone at the column base and thus can significantly improve the deformation and the energy dissipation capacities of the specimen.

- All of the tested specimens in socket connections exhibited initial stiffness lower than the theoretical elastic values, and for design purposes a coefficient $\alpha$ should be taken to account for the effectiveness of the socket connections.

\section{Acknowledgments}

The authors would like to express their sincere appreciation for the financial support from the Fundamental Research Funds for the Central Universities (Grant number: 2017XKQY051). The experimental work described in this paper was conducted at the Jiangsu Key Laboratory of Environmental Impact and Structural Safety in Civil Engineering in the China University of Mining and Technology, which is supported by a Project Funded by the Priority Academic Program Development of Jiangsu Higher Education Institutions (PAPD). Thanks are extended to the staffs and the students at the laboratory for their help during the test preparation and completion. The collaborative research was also facilitated by Jiangsu collaborative innovation center for building energy saving and construction technology.

\section{References}

[1] Elchalakani M., Zhao X.L. and Grzebieta R., "Tests on concrete filled double-skin (CHS outer and SHS inner) composite short columns under axial compression", Thin-Walled Structures, 40(5), 415-441, 2002

[2] Zhao X.L., Tong L.W. and Wang X.Y., "CFDST stub columns subjected to large deformation axial loading", Engineering Structures, 32(3), 692-703, 2010

[3] Kim, J.K. Kwak H.G. and Kwak J.H., "Behavior of hybrid double skin concrete filled circular steel tube columns", Steel \& Composite Structures, 14(14), 191-204, 2013.

[4] Ho J.C.M. and Dong C.X., "Improving strength, stiffness and ductility of CFDST columns by external confinement", Thin-Walled Structures, 75(75), 18-29, 2014.

[5] Ren Q.X., Hou C., Lam D. and Han L.H., "Experiments on the bearing capacity of tapered concrete filled double skin steel tubular (CFDST) stub columns", Steel \& Composite Structures, 17(5), 667-686, 2014

[6] Essopjee Y. and Dundu M., "Performance of concrete-filled double-skin circular tubes in compression", Composite Structures, 133, 1276-1283, 2015.

[7] Hassanein M.F., Kharoob O.F. and Gardner L., "Behaviour and design of square concretefilled double skin tubular columns with inner circular tubes", Engineering Structures, 100, 410-424, 2015.

[8] Hassanein M.F., Elchalakani M. and Patel V.I., "Overall buckling behaviour of circular concrete-filled dual steel tubular columns with stainless steel external tubes", Thin-Walled Structures, 115, 336-348, 2017

[9] Pons D., Espinós A., Albero V. and Romero M.L., "Numerical study on axially loaded ultrahigh strength concrete-filled dual steel columns", Steel \& Composite Structures, 26(6), DOI: 10.12989/scs.2018.26.6.705, 2018.

[10] Han L.H., Yang Y.F., "Cyclic performance of concrete-filled steel CHS columns under flexural loading", Journal of Constructional Steel Research, 61(4), 423-452, 2005.

[11] Han L.H., Huang H., Tao Z. and Zhao X.L., "Concrete-filled double skin steel tubula (CFDST) beam-columns subjected to cyclic bending", Engineering Structures, 28(12), 1698$1714,2006$. 
[12] Guerrini G., Restrepo J.I., Massari M. and Vervelidis A., "Seismic behavior of posttensioned self-centering precast concrete dual-shell steel columns", Journal of Structural Engineering, 141(4), 04014115, 2015.

[13] Lehman D.E. and Roeder C.W., "Foundation connections for circular concrete-filled tubes", Journal of Constructional Steel Research, 78(11), 212-225, 2012.

[14] Li X., Wu Y.P., Li X.Z., Xia J. and Lv H.L., "Punching shear strength of CFT bridge column to reinforced concrete four-pile cap connections", Journal of Bridge Engineering, 22(8), 04017036, 2017.

[15] Canha R.M.F., Jr K.D.B. and Debs M.K.E., "Analysis of the behavior of transverse walls of socket base connections", Engineering Structures, 31(3), 788-798, 2009.

[16] Tao Z., Han L.H. and Zhao X.L. "Behaviour of concrete-filled double skin (CHS inner and CHS outer) steel tubular stub columns and beam-columns", Journal of Constructional Steel Research, 60(8), 1129-1158, 2004

[17] Choi K., Xiao Y. and He W., "Confined concrete-filled tubular columns", Journal of
Structural Engineering, 131(3), 488-497, 2005.

[18] BS5400, "Concrete and Composite Bridges, Part 5", British Standard Institute, London, UK, 2006.

[19] AIJ, "Recommendations for Design and Construction of Concrete Filled Steel Tubular Structures", Architectural Institute of Japan, 1997.

[20] AISC-LRFD, "Load and Resistance Factor Design (LRFD) Specification for Structural Stee Buildings", Chicago: American Institute of Steel Construction, Inc. 2016.

[21] Eurocode 4, "Design of Composite Steel and Concrete Structures, Part1.1: General Rules and Rules for Buildings (Together with United Kingdom National Application Document), DD ENV 1994-1-1:1994”, London: British Standards Institution, 2005.

[22] Hsu H.L. and Lin H.W., "Improving seismic performance of concrete-filled tube to base connections", Journal of Constructional Steel Research, 62(12), 1333-1340, 2006.

[23] ASCE/SEI 41, "Seismic Rehabilitation of Existing Buildings", Reston, VA., 2013. 